\title{
KAMPUNG HIJAU PADA KAMPUNG KOTA (STUDI KASUS: KAMPUNG TANJUNG GEDONG RT.05/ RW.08, JAKARTA BARAT)
}

\author{
Nafiah Solikhah $^{1}$ dan Titin Fatimah ${ }^{2}$ \\ ${ }^{1}$ Prodi S1 Arsitektur, Jurusan Arsitektur dan Perencanaan, Universitas Tarumanagara Jakarta \\ Email:nafiahs@ft.untar.ac.id \\ ${ }^{2}$ Prodi S2 Arsitektur, Jurusan Arsitektur dan Perencanaan, Universitas Tarumanagara Jakarta \\ Email: titinf@ft.untar.ac.id
}

\begin{abstract}
Village is an integral part of cities in Indonesia since its inception. Each village is unique because it represents historical uniqueness, diverse physical patterns, complex and dynamic social systems. Jakarta City as the largest city in Indonesia has its own challenges in managing the Urban Villages. One of the urban villages in Jakarta is Tanjung Gedong Village, located in RT.05 / RW.08 Tomang Village, Grogol Petamburan District. The selection of RT.05 / $R W .08$ as a PKM activity partner was because the location of the target partner was around the UNTAR campus, so the PKM activity became a tangible manifestation of UNTAR's contribution to the surrounding environment. The Proposing Team has also conducted PKM activities at the Partner's location, so it is hoped that the proposed program will be sustainable. Tanjung Gedong Village RT.05 / RW.08 Tomang Village has an area of 1.3 hectares with a population of 300 people (60 households). Problems owned by Partners to create a healthy and comfortable environment for residents: First, spatial planning is not optimal and flexible to accommodate a variety of social activities from the community. Secondly, the partners currently lack green open space. The proposed solution is the Proposed Green Village Structuring Concept by involving active participation from Partners (RW-RT leadership, Residents) using 3 approaches, namely: Green Planning and Design, Green Open Space and Green community. The proposed Green Village concept is expected to overcome the problems faced by partners so that a healthy and comfortable residential environment for residents is achieved.
\end{abstract}

Keywords: Urban village; Green Village; Green Planning; Design

\begin{abstract}
ABSTRAK
Kampung merupakan bagian integral kota-kota di Indonesia sejak awal pembentukannya. Setiap kampung memiliki keunikan karena merepresentasikan kekhasan sejarah, pola fisik yang beragam, sistem sosial yang kompleks dan dinamis. Kota Jakarta sebagai kota terbesar di Indonesia memiliki tantangan tersendiri dalam mengelola Kampung Kotanya. Salah satu kampung kota di Jakarta adalah Kampung Tanjung Gedong yang terletak di RT.05/RW.08 Kelurahan Tomang, Kecamatan Grogol Petamburan. Pemilihan RT.05/RW.08 sebagai Mitra kegiatan PKM karena lokasi mitra sasaran berada di sekitar kampus 1 UNTAR, sehingga kegiatan PKM ini menjadi salah satu wujud nyata kontribusi UNTAR terhadap lingkungan sekitar. Tim Pengusul juga telah melakukan kegiatan PKM di lokasi Mitra, sehingga diharapkan program yang diusulkan akan berkesinambungan. Kampung Tanjung Gedong RT.05/RW.08 Kelurahan Tomang memiliki luasan 1,3 Ha dengan jumlah penduduk 300 orang (60 KK). Permasalahan yang dimiliki oleh Mitra untuk menciptakan lingkungan yang sehat dan nyaman untuk warga: Pertama, tata ruang belum optimal dan fleksibel untuk mewadahi beragam aktivitas sosial dari masyarakat. Kedua, saat ini mitra masih kekurangan ruang terbuka hijau. Solusi yang diusulkan adalah Usulan Konsep Penataan Kampung Hijau dengan melibatkan partisipasi aktif dari Mitra (pemangku pimpinan RW-RT, Warga) menggunakan 3 pendekatan, yaitu: Green Planning and Design, Green Open Space dan Green community. Usulan konsep Kampung Hijau diharapkan dapat mengatasi permasalahan yang dihadapi oleh mitra sehingga tercapai sebuah lingkungan hunian yang sehat dan nyaman untuk warga.
\end{abstract}

Kata Kunci: Kampung Kota; Kampung Hijau; Green Planning; Design

\section{PENDAHULUAN}

Kampung merupakan bagian integral kota-kota di Indonesia sejak awal pembentukannya (Sullivan, 1980; Krausse, 1975; Wertheim, 1958 dalam Setiawan, 2010: 215). Istilah kampung digunakan untuk menjelaskan fenomena perumahan di perkotaan yang dibangun secara swadaya atau mandiri oleh masyarakat, dan menjadi tumpuan sebagian besar warga kota. Istilah ini telah 
digunakan oleh pemerintah kolonial Belanda, yang pada awal abad 20 telah meluncurkan program kampung Verbrechting. Silas (dalam Setiawan, 2010: 12) menjelaskan bahwa sejak awal, pemerintah kolonial Belanda telah memisahkan secara tegas antara warga biasa atau warga kampung (Indlandsche Gementee) dengan warga priyayi, pamong praja/gedongan (Stads Gementee).

Kota Jakarta sebagai kota terbesar di Indonesia memiliki tantangan tersendiri dalam mengelola keberadaan kampung sebagai konsep bermukim dalam Arsitektur Kota Jakarta. Secara morfologi, Bernard Dorlean dalam Kusumawijaya (2004: 3) menyimpulkan bahwa Jakarta lebih menyerupai aglomerasi kampung daripada sebuah kota yang terstruktur. Pembangunan kota modern mendasarkan perencanaannya pada prinsip efisiensi, sedangkan aspek historis kurang dipertimbangkan. Jika Kota Jakarta ingin membangun wacana progresif sebagai kota modern, tentunya modern yang tetap berkarakter budaya atau berdasarkan akar sejarah. Ketika konsep modern hanya mengadopsi konsep dari Barat, tanpa melihat akar budaya maka akan berdampak adanya konflik sosial, sehingga perencanaan dan perancangan kota Jakarta tidak bisa terlepas dari proses perkembangannya. Keberagaman karakteristik geografis wilayah kota Jakarta juga harus dipertimbangkan dalam merencanakan dan merancang Arsitektur kota Jakarta, seperti kampung di tepi pantai, di muara sungai, lahan berawa, dan lain sebagainya. Diperlukan strategi untuk menjadikan kampung sebagai bagian penting masa depan kota Jakarta, yaitu:

1. Program perbaikan kampung harus dilakukan secara holistik yang melihat kampung sebagai satu sistem fisik, sosial, ekonomi, dan politik kota yang tidak dapat dipisahkan.

2. Mengintegrasikan kampung dalam sistem kota. Perubahan orientasi perencanaan dan pembangunan kota.

3. Menjadikan kampung sebagai defensible life space atau ruang kehidupan yang dapat dipertahankan (Friedmann, 1992 dalam Setiawan, 2010: 218)

Salah satu kampung kota di Jakarta adalah Kampung Tanjung Gedong RT.05/RW.08 Kelurahan Tomang, Kecamatan Grogol Petamburan. Pemilihan RT.05/RW.08 sebagai Mitra kegiatan PKM karena lokasi mitra sasaran berada di sekitar kampus 1 UNTAR, sehingga kegiatan PKM ini menjadi salah satu wujud nyata kontribusi UNTAR terhadap lingkungan sekitar.

\section{Analisis Situasi}

Lokasi mitra berada di sisi Timur Kampus 1 Universitas Tarumanagara dengan jarak $\pm 450 \mathrm{~m}$ (Gambar 1). Sebagai di Jakarta salah satu kampung kota, Kampung Tanjung Gedong berkembang di tengah-tengah perkembangan bangunan tinggi yang mengelilinginya, seperti: Kampus 1 Untar, Kampus Trisakti, Apartemen Tomang Park. Kampung Tanjung Gedong RT.05/RW.08 Kelurahan Tomang memiliki luasan 1,3 Ha dengan jumlah penduduk 300 orang (60 KK).

Berdasarkan hasil tinjauan lapangan dan kegiatan PKM yang pernah ketua Tim laksanakan sebelumnya yaitu Redesain Kantor Sekretariat dan Ruang Publik RW. 08 Kelurahan Tomang, Kecamatan Grogol Petamburan dan Penataan Ruang Publik RW. 08 Kelurahan Tomang, Kecamatan Grogol Petamburan dapat diketahui bahwa aktivitas sosial masyarakat masih aktif, antara lain: kegiatan Karang Taruna, Posyandu, Pospindu, Sekretariat Jumantik, Peringatan Hari Besar Keagamaan (Gambar 1). Latar belakang warga yang tinggal di lokasi Mitra cukup beragam baik baik dari warga pendatang maupun warga asli Jakarta (Betawi), namun demikian warga asli Jakarta lebih dominan. 


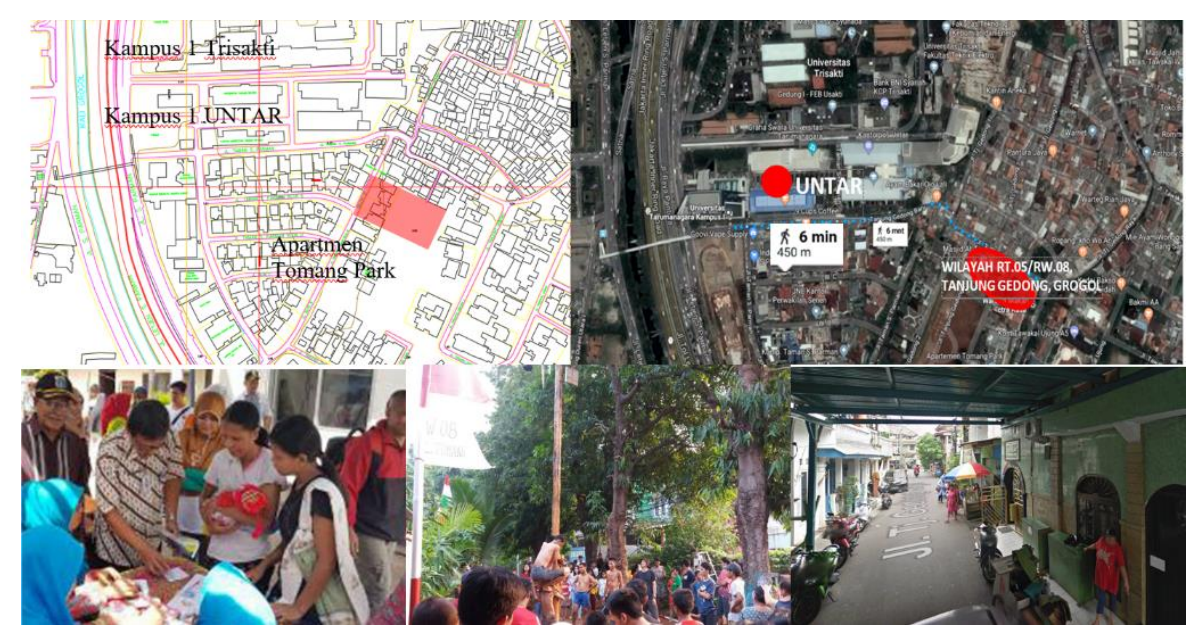

Gambar 1. Lokasi Mitra dan Gambaran Umum Aktivitas Warga (Sumber: Survey Tim, 2018)

Aktivitas sosial yang dilakukan warga lebih sering dilakukan di area terbuka. Ruang sebagai wadah harus mampu menyediakan lingkungan yang kondusif bagi terpenuhinya syarat interaksi, yaitu memberi peluang bagi terjadinya kontak dan komunikasi sosial. Interaksi sosial dapat terjadi dalam bentuk aktivitas yang pasif seperti sekedar duduk menikmati suasana atau mengamati situasi dan dapat pula terjadi secara aktif dengan berbincang bersama orang lain membicarakan suatu topik atau bahkan melakukan kegiatan bersama

\section{Permasalahan Mitra}

Berdasarkan kunjungan awal Tim ke lokasi serta wawancara dengan Bapak M. Yusuf selaku ketua RW. 08, Kelurahan Tomang, Kecamatan Grogol Petamburan terdapat beberapa permasalahan yang dihadapi oleh Mitra terutama untuk menciptakan lingkungan yang sehat dan nyaman untuk warga.

Pertama, Permasalahan Fisik Keruangan. Penataan tata ruang belum optimal dan fleksibel untuk mewadahi beragam aktivitas sosial dari masyarakat (Karang Taruna, Posyandu, Pospindu, Jumantik, dll). Hal lain terkait aspek keruangan adalah kurangnya ruang aktivitas masyarakat akibat tingginya kepadatan bangunan. Lahan parkir juga memerlukan penyelesaian, sehingga nantinya diharapkan area bahu jalan kampung/gang tidak menjadi parkir mobil dan motor. Pedestrian juga kurang terencana sehingga kurangnya jalur pedestrian yang baik (Gambar 2).

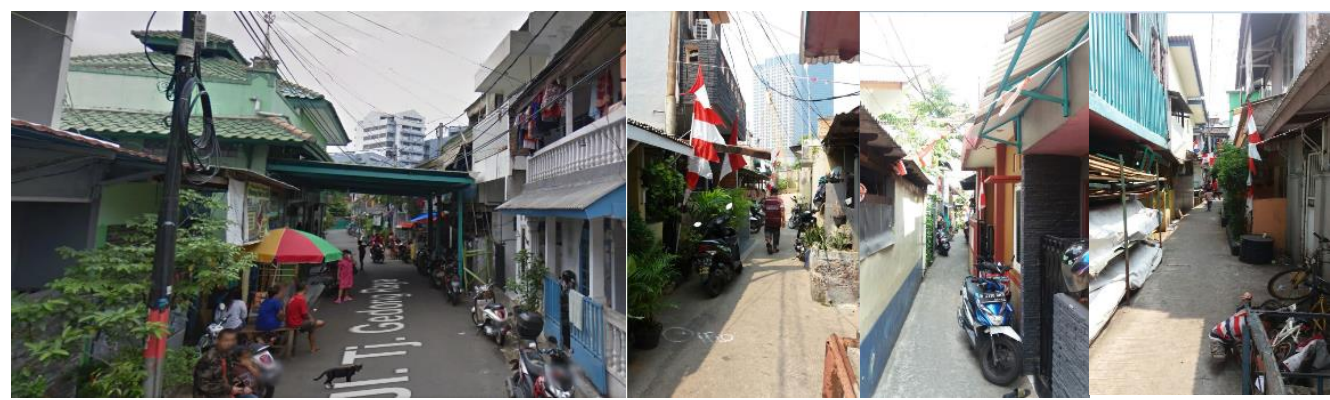

Gambar 2. Permasalahan Fisik Keruangan (Sumber: Survei, 2018)

Kedua, permasalahan lingkungan. Saat ini mitra masih kekurangan ruang terbuka hijau. Ruang terbuka hijau yang ada adalah taman di samping kantor sekretariat RW.08 (Gambar 3). Dengan adanya pembangunan beberapa bangunan tinggi di sekitar lokasi Mitra, maka kualitas air tanah 
menurun. Saat ini sampah yang dihasilkan warga belum dikelola secara tersistem sehingga menjadi sampah yang tidak produktif

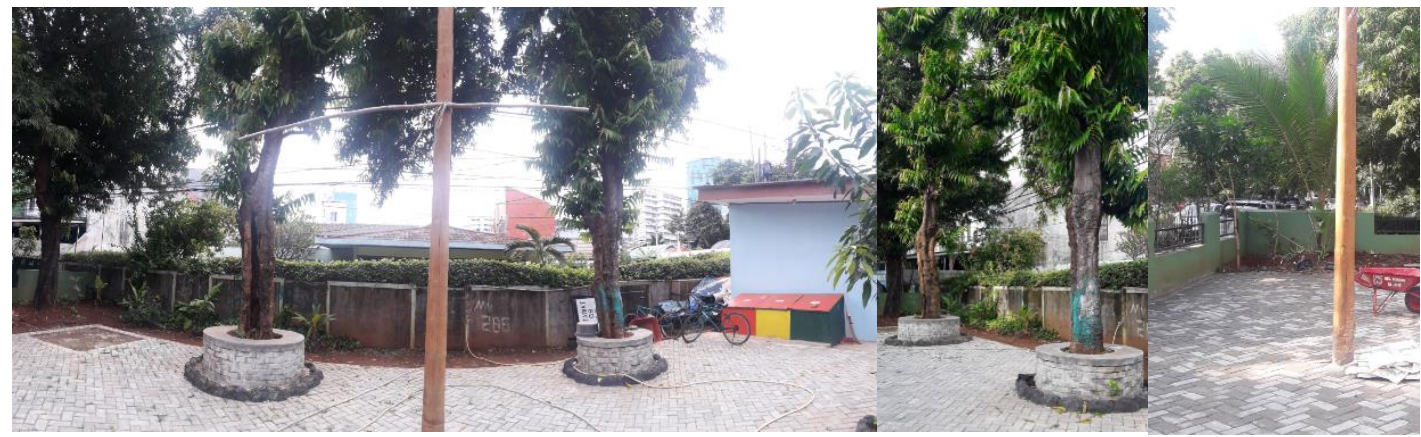

Gambar 3. Optimalisasi Ruang Terbuka sebagai Permasalahan Lingkungan

(Sumber: Survei, 2018)

\section{KAMPUNG HIJAU SEBAGAI SOLUSI PENATAAN KAMPUNG KOTA}

Konsep kampung hijau merupakan salah satu solusi untuk menyelesaikan permasalahan yang muncul di kampung kota yang diadopsi dari Program Pengembangan Kota Hijau (P2KH) Kementrian Pekerjaan Umum (PU). Program ini diharapkan mampu menumbuhkembangkan kesadaran masyarakat akan pentingnya peningkatan mutu lingkungan yang tertata dan terkelola dengan baik serta turut menjaganya agar tercipta suatu lingkungan yang bersih, sehat serta berkualitas.

Berdasarkan Konsep P2KH, terdapat beberapa aspek Kota yang Ramah Lingkungan, yaitu: memanfaatkan secara efektif dan efisien sumberdaya air dan energi, mengurangi limbah, menerapkan sistem transportasi terpadu, menjamin kesehatan lingkungan mensinergikan lingkungan alami dan buatan, berdasarkan perencanaan dan perancangan kota yang berpihak pada prinsip-prinsip pembangunan berkelanjutan (lingkungan, sosial dan ekonomi). Adapun Atribut Kota Hijau P2KH meliputi: Green Planning and Design, Green Openspace, Green waste, Green Transportation, Green Water, Green Energy, Green Building, Green Community.

Berdasarkan permasalahan yang dimiliki mitra, maka solusi usulan konsep Kampung Hijau yang diusulkan menggunakan 3 pendekatan, yaitu

a. Green Planning and Design, meningkatkan kualitas rencana tata ruang dan rancang kota yang lebih sensitive terhadap agenda hijau (Permasalahan Fisik Keruangan).

b. Green Open Space, meningkatkan kualitas dan kuantitas RTH sesuai dengan karakteristik kawasan (Permasalahan Lingkungan).

c. Green community, yaitu meningkatkan partisipasi aktif masyarakat atau komunitas.

\section{Studi Kasus: Kampung Hijau Hidroponik Pengadegan}

Kampung Hidroponik Pengadegan terletak di RW 01, RW 03, RW 07 dan RW 08, Kelurahan Pengadegan, Kecamatan Pancoran, Jakarta Selatan (Gambar 4). 


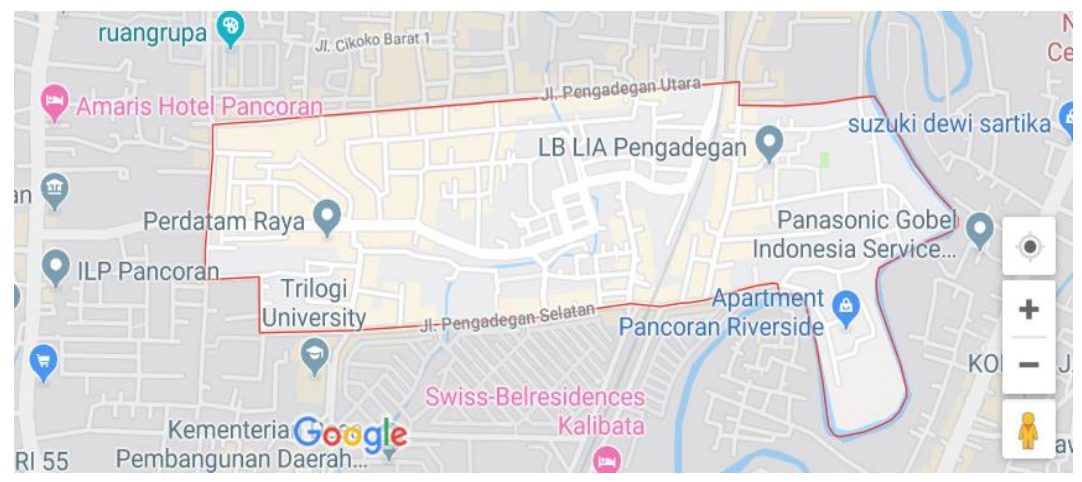

Gambar 4. Peta Kampung Pengadegan (Sumber: Diolah dari Google Map 2019)

Program Kampung Hidroponik diinisiasi oleh Bapak Mursyid, lurah setempat. Beliau memprakarsai dan mengampanyekan Kampung Hidroponik dengan menerapkan ilmu yang didapatnya di bangku kuliah Magister Manajemen Agribisnis Institut Pertanian Bogor (IPB). Atas upayanya tersebut, banyak warga yang kemudian tertarik melakukannya. Pekarangan para warga yang sebelumnya kumuh kini sudah dipenuhi dengan aneka tanaman, serta menyediakan tempat sampah masing-masing (Marsoum, 2018). Sebagai langkah awal, Bapak Mursyid menjadikan kantor kelurahan yang dipimpinnya sebagai laboratorium percobaan. Ruang-ruang di sisi kantor dijadikannya sebagai ladang hidroponik serta pembibitan ikan. Pemandangan asri yang dilihat warga saat datang ke kelurahan itu membuat mereka tertarik. Mereka lalu belajar untuk mengetahui bagaimana cara bercocok tanam dengan sistem hidroponik yang kemudian diaplikasikan ke kawasan pemukiman masing-masing.

Warga masyarakat sangat bersemangat dalam berpartisipasi dalam kegiatan ini. Berawal dari pelatihan kepada ibu-ibu PKK, yang kemudian menjadi virus yang menyebar ke seluruh warga hingga warga ramai-ramai membuat ladang hidroponik di sekitar rumahnya. Saat ini sudah ada empat RW yang mengaplikasikan Kampung Hidroponik, yakni RW 01, RW 03, RW 07 dan RW 08. Dan akan bertambah lagi RW yang mengikuti. Menurut Mursyid, pertanian modern yang dilakukan warga akan mampu menciptakan ketahanan pangan selain menambah ruang hijau yang kini sedang digencarkan (Silaen, 2018).

Di Kampung Hidroponik Pengadegan terdapat satu tempat yang dinamakan Pos Pemantau Tanaman Hidroponik. Dengan sukarela warga bergantian berjaga di pos ini untuk memastikan tidak ada tanaman liar yang justru merusak dan mengotori lingkungan. Selain itu dibentuk juga tim dengan ada koordinator lingkungan setempat.

Kegiatan Kampung Hidroponik dilakukan secara mandiri oleh warga yang didukung penuh secara resmi oleh Pemerintahan Kelurahan Pangadegan (Gambar 5). Sebagian dana pembuatan hidroponik diperoleh dari program Corporate Social Responsibility (CSR) PT Wika dan Palang Merah Indonesia. Kegiatan ini juga didukung oleh Suku Dinas Kelautan, Pertanian dan Ketahanan Pangan (KPKP) Kota Jakarta Selatan yaitu dukungan teknis berupa penyuluhan maupun bibit tanaman dan ikan jika warga mengajukan. Program kampung hidroponik di Pengadegan merupakan bagian dari mitigasi program masyarakat tangguh banjir dukungan dari PMI Pusat dan Zurich Insurance (Hadi dan Murtopo, 2018). 

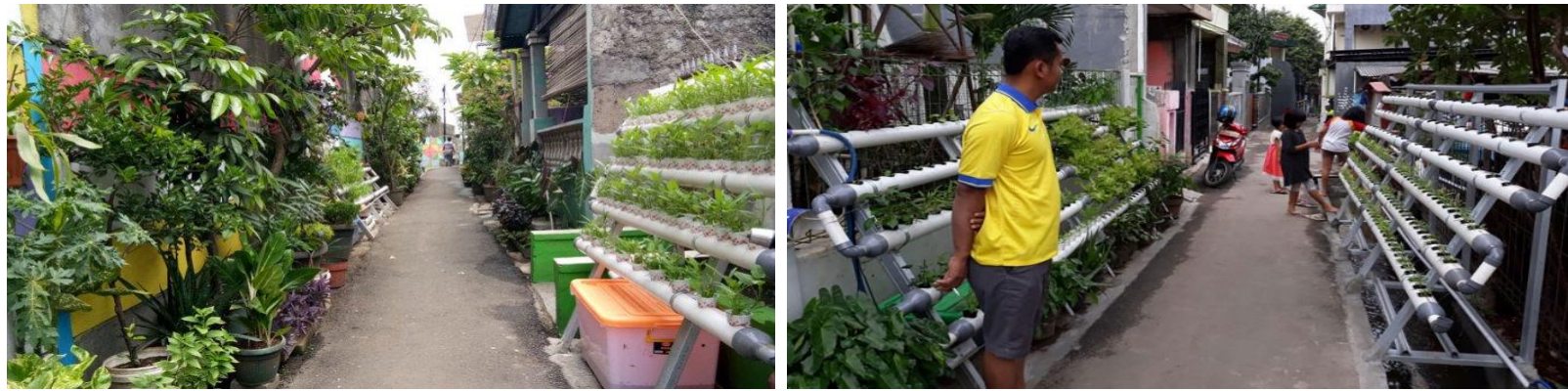

Gambar 5. Pemukiman di kawasan Pengadegan yang dipenuhi tanaman hidroponik.

(Sumber: Amanes. 2018/ https://www.inovasee.com)

\section{METODE PELAKSANAAN}

Program PKM Penataan Kampung Hijau ini membutuhkan waktu selama 4 bulan terbagi atas 3 tahap, dimana pada tiap-tiap tahapan saling terkait dan menguatkan sehingga program yang akan dilaksanakan dapat berjalan sesuai dengan harapan. Tahapan tersebut adalah :

a. Persiapan, yaitu: Melakukan identifikasi masalah yang nyata di lingkungan, melakukan analisa, mencari alternatif yang dapat dilaksanakan, memilih solusi. Pada tahap ini TIM PKM melakukan identifikasi awal di lapangan untuk melakukan analisis situasi (pengamatan dan berdiskusi) dengan Perwakilan Mitra (Ketua RW.08 dan Karang Taruna) sehingga menghasilkan perumusam permasalahan yang dimiliki oleh Mitra.

\section{b. Pelaksanaan,}

\section{Tahap 1: Green Planning and Design}

Kegiatan yang dilaksanakan yaitu: a). Mengumpulkan potensi masyarakat untuk dilibatkan dalam program. b). Memberikan pengetahuan, keterampilan dan kemampuan kepada masyarakat agar mereka dapat melaksanakan program tersebut.

Luaran pada tahap ini berupa: a. informasi karakter dan potensi mitra; b. gambar kerja rencana tata ruang dan rancang kota dalam bentuk gambar kerja 2 Dimensi dan Gambar Perspektif 3 Dimensi; c. realisasi usulan desain (ruang publik RW. 08, dan penataan koridor di samping Masjid At-Taufiq sebagai area percontohan).

\section{Tahap 2: Green Open Spaces}

Melanjutkan penataan Ruang Publik berupa realisasi pengadaan vertikultur dan Taman TOGA

\section{Tahap 3: Green Community (Sosialisasi)}

Hasil kegiatan akan dikemas menjadi materi Sosialisasi (berupa booklet, papan informasi dan presentasi kepada warga).

\section{HASIL DAN PEMBAHASAN}

Untuk menghasilkan luaran berupa solusi yang sesuai dengan permasalahan mitra, maka perlu dilakukan proses kemitraan. Tahap awal kegiatan dimulai dari diskusi antara tim PKM UNTAR dengan pihak mitra yang diwakili oleh Bapak M.Yusuf selaku ketua RW. 08 (Gambar 6). Adapun hasil diskusi dengan mitra antara lain:

a. Mitra mengusulkan beberapa program kegiatan bersama yang nantinya dapat diwadahi sesuai dengan kebutuhan masyarakat, seperti: bank sampah, taman refleksi, taman bermain anak, Taman Tanaman Obat Keluarga (TOGA), dll 
b. Penentuan batasan area usulan desain sebagai area percontohan. Mitra mengusulkan agar area percontohan nantinya dapat direalisasikan agar menjadi inspirasi dan penyemangat bagi wilayah di sekitarnya.

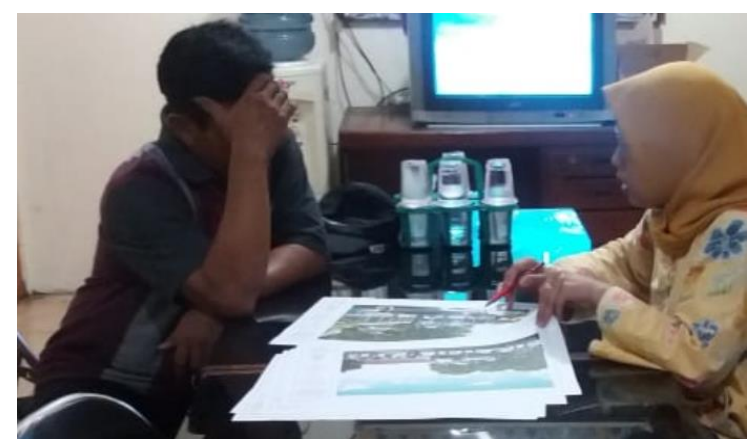

Gambar 6. Diskusi Tim PKM UNTAR dengan Mitra (Sumber: Dokumentasi Tim PKM, 2019)

Dari proses diskusi internal Tim yang mempertimbangkan permintaan Mitra maka dihasilkan batasan area usulan konsep desain awal Kampung Hijau Tanjung Gedong yang mewadahi beberapa aktivitas. Luaran lain yaitu penentuan konsep awal Kampung Hijau Tanjung Gedong sesuai dengan kebutuhan Mitra. Pertama, Taman Sekretariat RW. 08 sebagai generator Kampung Hijau Tanjung Gedong sekaligus sebagai pusat aktivitas warga yang dilengkapi bank sampah, area refleksi, instalasi vertikultur, taman Tanaman Obat Keluarga (TOGA). Untuk lebih jelasnya dapat dilihat pada Gambar 7.

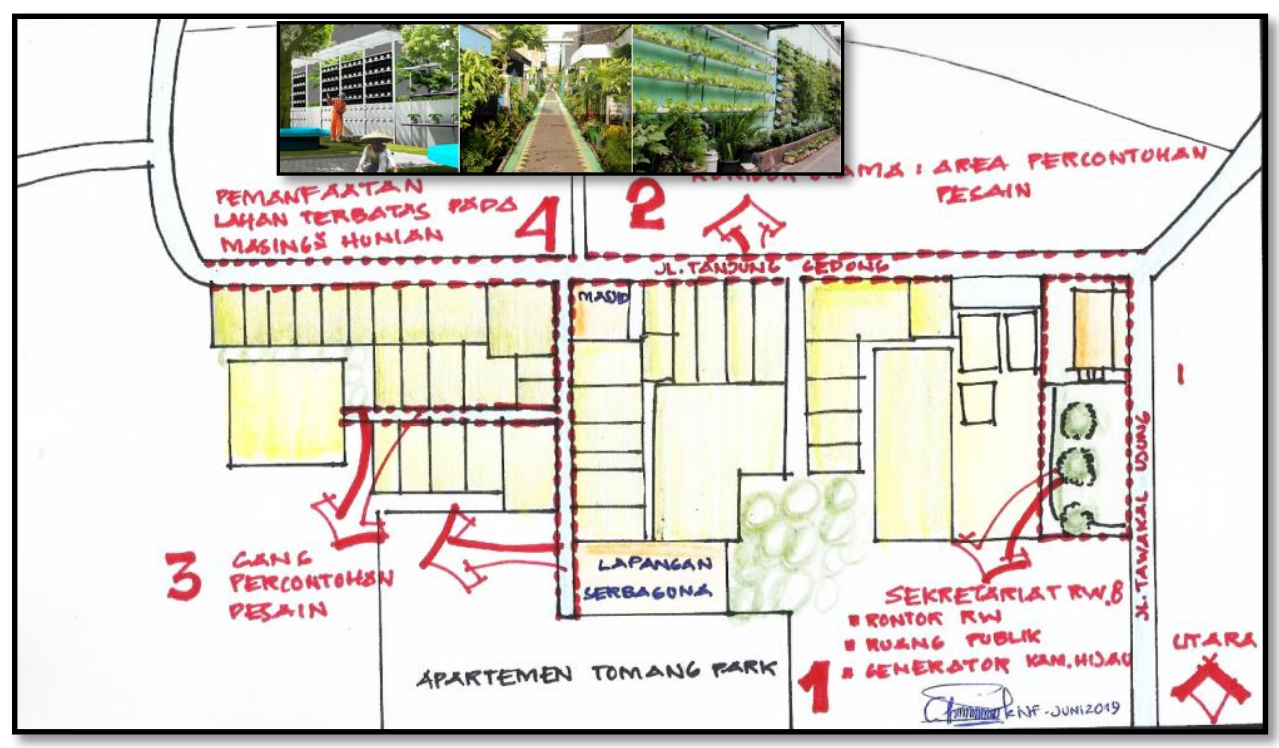

Gambar 7. Batasan dan Konsep Dasar Kampung Hijau Tanjung Gedong (Sumber: Tim PKM, 2019)

Untuk meningkatkan kualitas rencana tata ruang dan rancang kota yang lebih sensitive terhadap agenda hijau maka batasan dan konsep dasar Kampung Hijau yang telah disepakati antara Tim PKM UNTAR dengan Mitra dikembagkan dalam bentuk Perencanaan dan Perancangan Kampung Hijau (Green Planning and Design).

Tahap ini diawali dengan mengumpulkan potensi masyarakat untuk dilibatkan dalam program. Selanjutnya tim PKM berlaku sebagi fasilitatyor yang nantinya akan memberikan pengetahuan, 
keterampilan dan kemampuan kepada masyarakat agar mereka dapat melaksanakan program Kampung Hijau yang direncanakan. Luaran pada tahap ini yaitu berupa mind map penelusuran masalah sampai dengan usulan konsep Desain yang berhasil disusun bersama antara warga RT. 05/ RW. 08 Kampung Tanjung Gedong (mitra) dengan tim PKM UNTAR (Gambar 8).

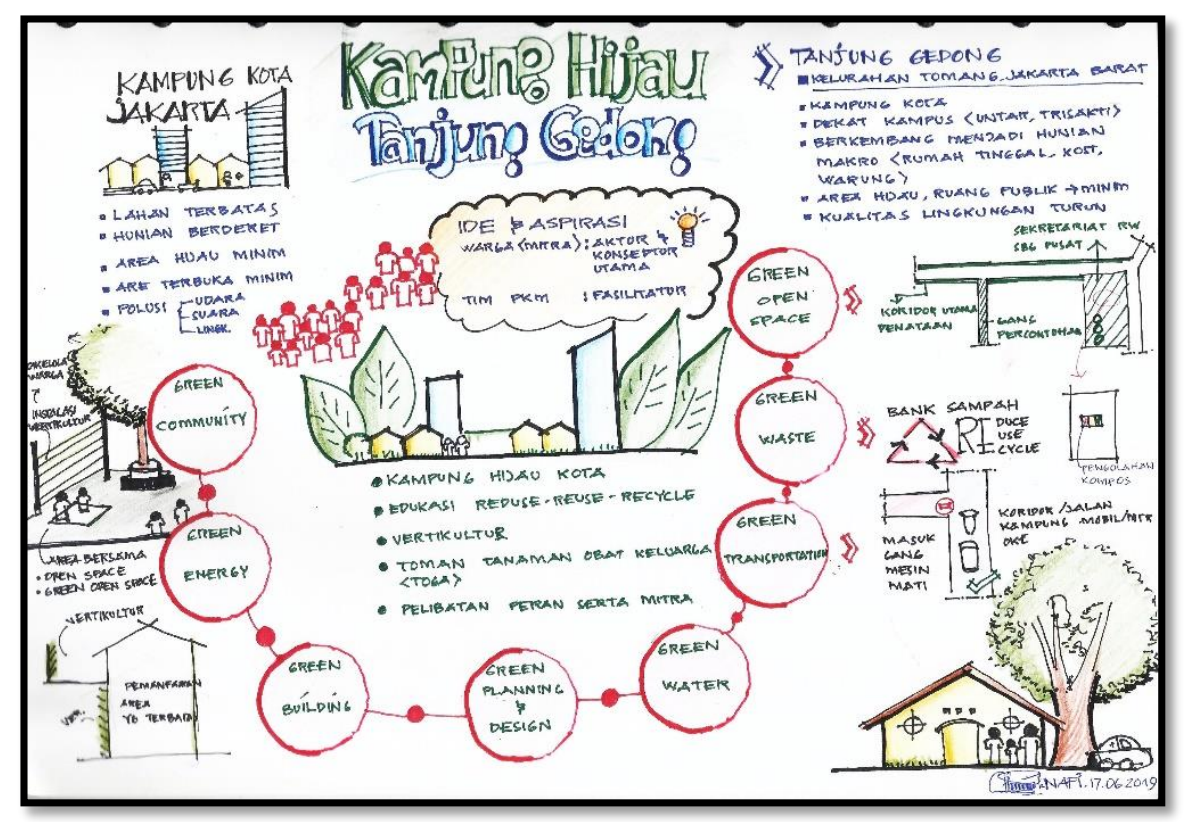

Gambar 8. Konsep Kampung Hijau Tanjung Gedong

(Sumber: Tim PKM, 2019)

Selanjutnya Tim PKM bersama dengan mitra mulai menyusun ide-ide desain pada area ataupun bagian detail yang diusulkan. Untuk lebih jelasnya dapat dilihat pada gambar 9 s.d. gambar 12 .

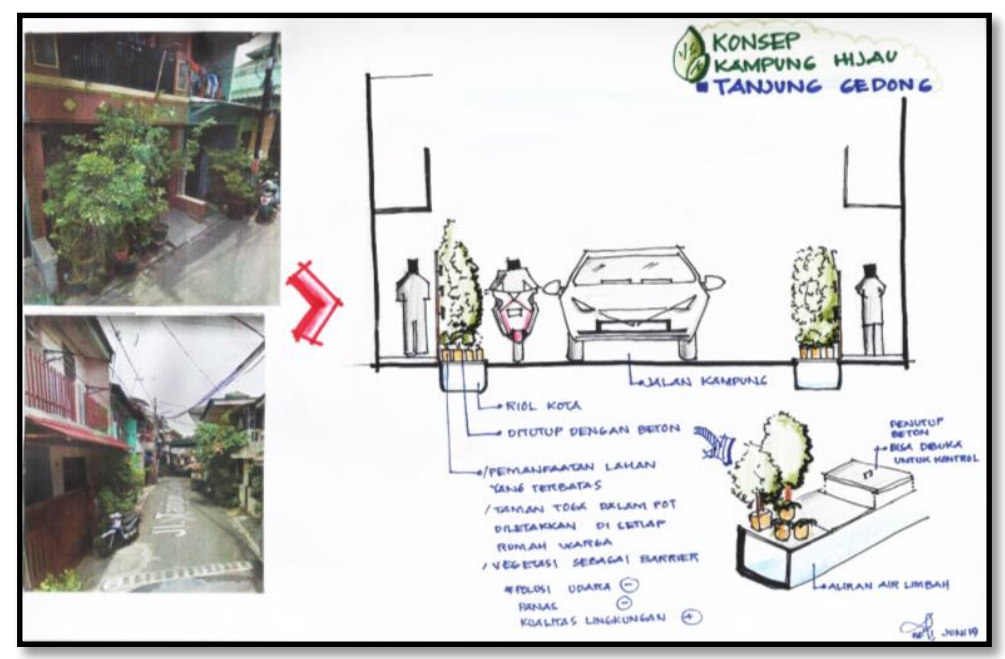

Gambar 9. Usulan Desain pada Koridor Utama Kampung Hijau Tanjung Gedong (Sumber: Tim PKM, 2019) 


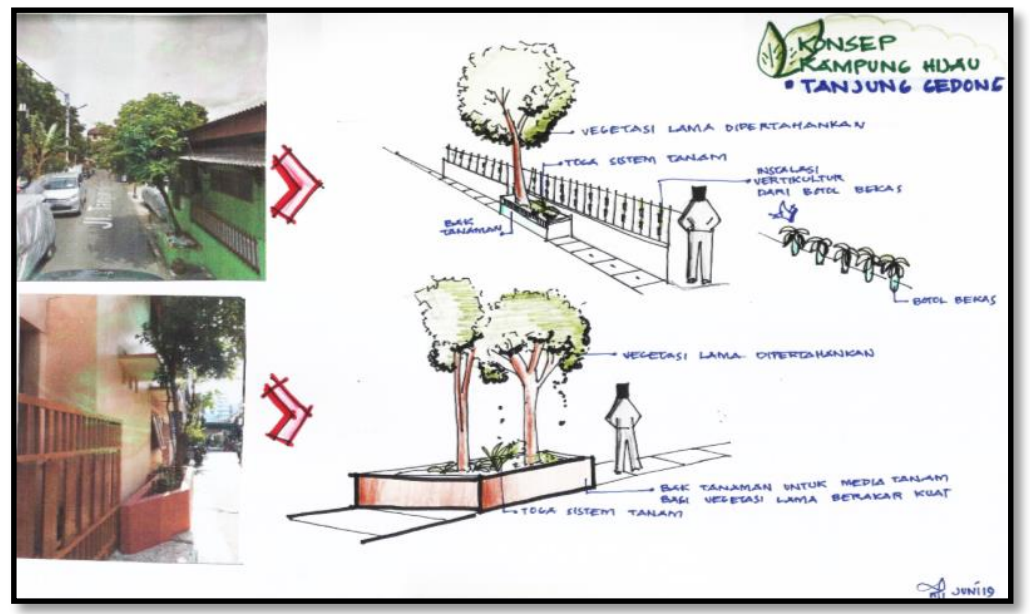

Gambar 10. Usulan Desain pada Tepi Koridor Kampung Hijau Tanjung Gedong (Sumber: Tim PKM, 2019)
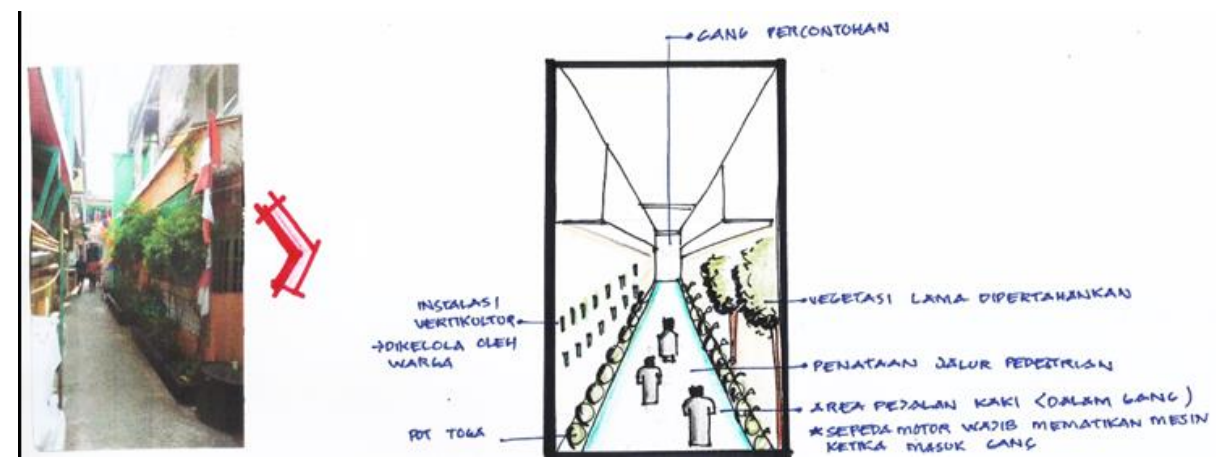

Gambar 11. Usulan Desain pada Gang Kampung Hijau Tanjung Gedong

(Sumber: Tim PKM, 2019)

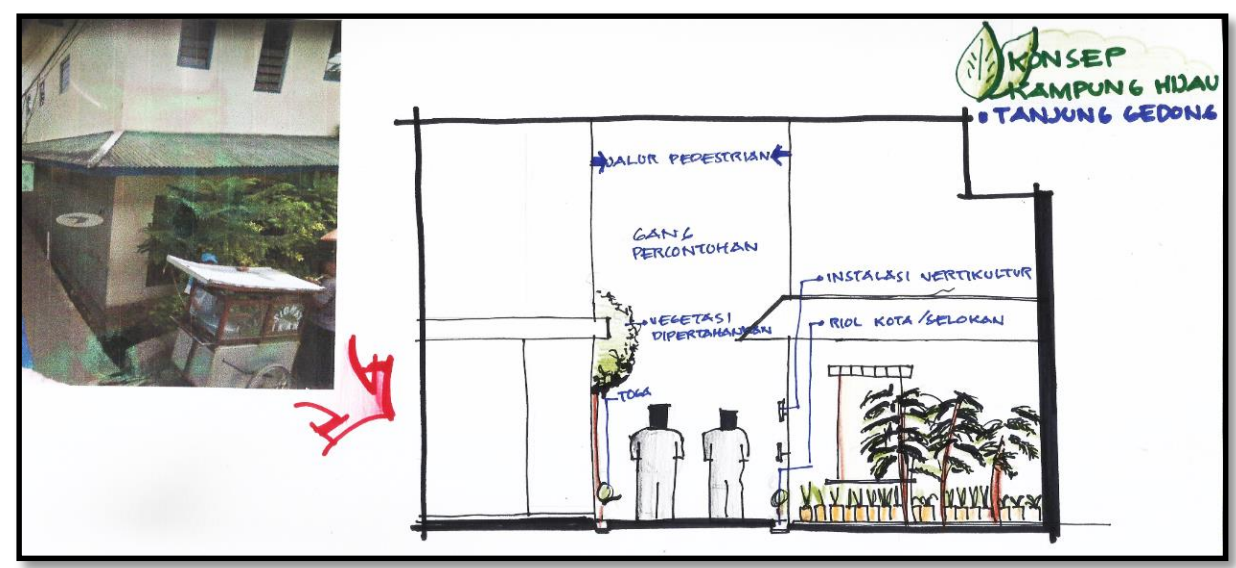

Gambar 12. Usulan Desain pada Akses Gang Kampung Hijau Tanjung Gedong (Sumber: Tim PKM, 2019)

Pada awal diskusi Mitra mengusulkan adanya area percontohan (pilot project) yang nantinya dapat direalisasikan agar menjadi inspirasi dan penyemangat bagi wilayah di sekitarnya. Oleh karena itu, tim berencana melanjutkan penataan Ruang Publik berupa realisasi pengadaan vertikultur dan Taman TOGA. 


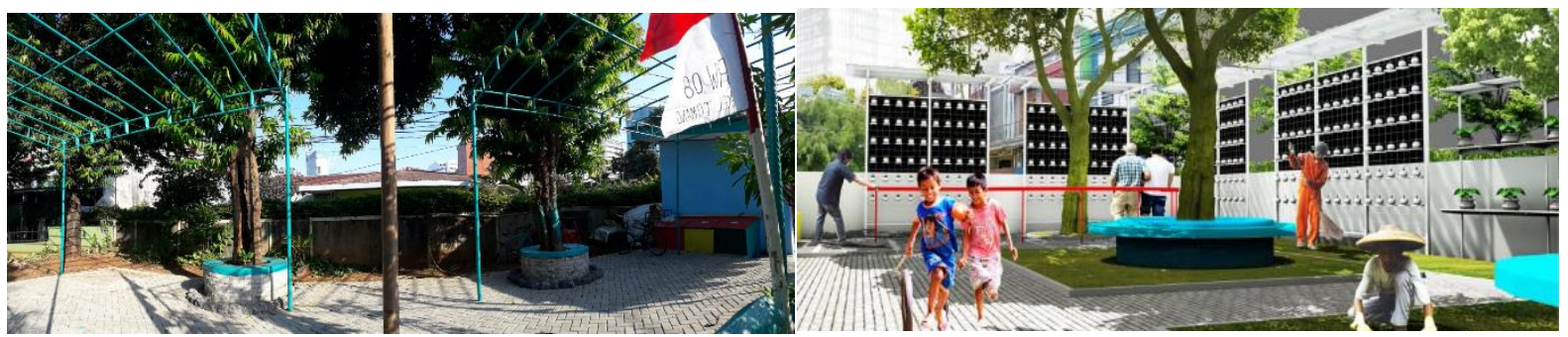

Gambar 13. Progress Realisasi Usulan Desain pada Ruang Publik RW. 08, Tanjung Gedong

(Sumber: Tim PKM, 2019)

Setelah Usulan Konsep Kampung Hijau tersusun dan terealisasi, maka perlu dilakukan sosialisasi kepada mitra yaitu warga RW.08. Dalam kegiatan sosialisasi warga akan dibekali beberapa pengetahuan dasar mengenai fungsi dan peranan mereka dalam keberlangsungan Kampung Hijau Kampung Tanjung Gedong sehingga mitra diharapkan dapat berperan aktif mewujudkan kawasan hijau edukatif yang telah direncanakan dan dilaksanakan oleh tim bersama dengan mitra.

\section{KESIMPULAN DAN SARAN}

\section{Kesimpulan}

Berdasarkan PKM yang telah TIM laksanakan, maka dapat diambil kesimpulan bahwa Konsep Kampung Hijau menjadi solusi yang menarik dalam penataan kampung kota, terutama di kotakota besar seperti Jakarta. Keberlanjutan program Kampung Hijau akan terlaksana dengan baik jika sejak awal perencanaan sampai dengan pengelolaannya ikut melibatkan peran serta masyarakat secara aktif.

Ide dasar usulan konsep Kampung Hijau di Kampung Tanjung Gedong yang berada di kawasan padat penduduk salah satunya didasari oleh mulai menurunnya kualitas lingkungan.

Usulan konsep Kampung Hijau Tanjung Gedong menggunakan 3 pendekatan, yaitu:

a. Green Planning and Design, rencana tata ruang dan rancang kota yang mengedepankan konsep ramah lingkungan (reduce, reuse, recycle);

b. Green Open Space, meningkatkan kualitas dan kuantitas RTH sesuai dengan karakteristik kawasan (Ruang Publik di Sekretariat RW. 08 sebagai pusat kegiatan);

c. Green community, yaitu meningkatkan partisipasi aktif masyarakat atau komunitas.

\section{Saran}

Konsep kampung hijau merupakan salah satu solusi untuk menyelesaikan permasalahan yang muncul di kampung kota yang diadopsi dari Program Pengembangan Kota Hijau (P2KH) Kementrian Pekerjaan Umum (PU). Program ini diharapkan mampu menumbuhkembangkan kesadaran masyarakat akan pentingnya peningkatan mutu lingkungan yang tertata dan terkelola dengan baik serta turut menjaganya agar tercipta suatu lingkungan yang bersih, sehat serta berkualitas.

Dalam menyusun konsep Kampung Hijau harus disesuaikan dengan karakteristik dan potensi yang dimiliki oleh mitra. Hal ini dengan tujuan agar nantinya konsep yang disusun sesuai dengan kebutuhan masyarakat setempat.

Ucapan Terima Kasih (Acknowledgement)

Kami mengucapkan terima kasih atas terlaksanaya program PKM ini kepada: 
1. Direktorat Penelitian dan Pengabdian Kepada Masyarakat Universitas Tarumanagara yang telah memberikan dana PKM;

2. Bapak M. Yusuf selaku ketua RW. 08, Kelurahan Tomang sebagai mitra yang kooperatif;

3. Serta kepada semua pihak yang telah membantu terlaksananya program ini.

\section{REFERENSI}

Kusumawijaya, M. (2004). Jakarta: metropolis tunggang langgang. Gagas Media, Jakarta.

Hadi, F. \& Murtopo. (2018). Kampung hidroponik pengadegan bakal mendunia. URL: https://wartakota.tribunnews.com/2018/01/23/kampung-hidroponik-pengadegan-bakalmendunia. Diakses tanggal 15 Juni 2019

Marsoum, A. (2018). Bukan di Jepang, Kampung Hidroponik yang Hijau Ini Ada di Pengadegan: Ini adalah kampung hijau yang siap mendunia. URL: https://www.inovasee.com/kampunghidroponik-pengadegan-35836/. Diakses tanggal 15 Juni 2019

Program Pengembangan Kota Hijau (P2KH) 2011, Lokakarya "Perubahan Iklim dan Kota Hijau:

Dari Konsep Menuju Rencana Aksi”. Direktur Perkotaan Kementerian Pekerjaan Umum Direktorat Jenderal Penataan Ruang. Jakarta, 27 September 2011

Setiawan, B. (2010). Kampung Kota dan Kota Kampung: Potret Tujuh Kampung di Kota Jogja. Pusat Studi Lingkungan Hidup Universitas Gadjah Mada, Yogyakarta.

Solikhah, N., dkk (2018). Redesain Kantor Sekretariat dan Ruang Publik RW. 08, Kelurahan Tomang, Kecamatan Grogol Petamburan, Jakarta Barat. Laporan PKM. Direktoral Penelitian dan Pengabdian kepada Masyarakat (DPPM) Universitas Tarumanagara

Silaen, F. 2018. Kampung Hidroponik yang hijau di Pengadegan. URL: https://beritagar.id/artikel/piknik/kampung-hidroponik-yang-hijau-di-pengadegan. Diakses tanggal 15 Juni 2019 